\title{
Hand Preference in 4-Month-Old Infants: Global or Local Processing of Objects in the Haptic Mode
}

\section{A. Streri}

\section{(2) OpenEdition}

1 Journals

Electronic version

URL: http://journals.openedition.org/cpl/150

DOI: $10.4000 / \mathrm{cpl} .150$

ISSN: $1379-6100$

Publisher

Centre PsyCLÉ

Printed version

Date of publication: 1 April 2002

\section{Electronic reference}

A. Streri, « Hand Preference in 4-Month-Old Infants: Global or Local Processing of Objects in the Haptic Mode », Current psychology letters [Online], 2002/1, 7 | 2002, Online since 04 September 2003, connection on 08 September 2020. URL : http://journals.openedition.org/cpl/150 ; DOI : https:// doi.org/10.4000/cpl.150

This text was automatically generated on 8 September 2020

(C) All rights reserved 
Hand Preference in 4-Month-Old Infants: Global or Local Processing of Objects in the Haptic Mode

A. Streri 